\title{
The Link between Export Performance and Export Development: Does Managements' Motivation Play a Role?
}

\author{
Jayanty Kuppusamy and R.N. Anantharaman \\ Faculty of Business and Law, Multimedia University (Malacca Campus), Malacca, Malaysia
}

\begin{abstract}
Exporting is the most common and widely used mode to enter into business at an international level. Export performance is crucial to identify the performance level of the organizations. This measure determines whether the organization is performing well. However, export development is also critical since it provides information on the future direction of the organization. Therefore, the aim of this study is to identify the link between export performance and export development of organizations. In addition, managements' motivation is tested to identify its influence on export performance and also export development. Furthermore, the study also aims to identify the influence of managements' motivations in the relationship between export performance and export development. Correlation analysis and multiple regression analysis are used to test the data. The respondents of the study are organizations in the manufacturing sector. 212 of the contacted organizations responded. The findings revealed that export performance has a direct link with export development. Managements' motivation is found to have a direct influence on export performance and export development. In addition, managements' motivation also has a role in the relationship between export performance and export development whereby it serves as a mediator. Therefore, management has to be motivated in order for the organization to pursue further export development, even though they have a favorable export performance level.
\end{abstract}

Keywords: Managements' motivation, export performance, export development.

\section{Introduction}

Organizations intending to further their business internationally have generally given more preference to exporting, although there are numerous modes to enter international market. This is clearly stated by Dhanaraj and Beamish (2003) who pointed out that exporting has become the predominant mode of international expansion. Furthermore, governments of developing countries including Malaysia encourage organizations to expand their business internationally and the common method is through exporting. Malaysia had formulated a long term industrial plan known as the Industrial Master Plan which is currently in its third stage. The Industrial Master Plan 3 has identified intensifying trade as one of its strategic thrusts. Thus, there is a need to give importance towards promoting export. Malaysia External Trade Development (MATRADE) provides various programmes in assisting organizations in terms of exporting.

Copyright (C) 2012 Jayanty Kuppusamy and R.N. Anantharaman. This is an open access article distributed under the Creative Commons Attribution License unported 3.0, which permits unrestricted use, distribution, and reproduction in any medium, provided that original work is properly cited. Contact author: Jayanty Kuppusamy E-mail: jayanty.kuppusamy@mmu.edu.my 
A number of studies have been researched on export performance and export performance determinants (Aaby and Slater, 1989; Styles and Ambler, 1994). However, there is hardly any linkage made on the influence of export performance on export development or further export expansion plans. Export performance has been identified as an antecedent and tested on its relationship with commitment (Lages and Montgemory, 2004). However, for this study export performance is tested on its influence on future export development. This is an important area of study since developing export is beneficial to both the organization from a micro perspective and the nation from a macro perspective. Furthermore, countries such as Malaysia have actively encouraged exporting activities to increase the trade level. The benefits of exporting have been explained by Albaum et al. (2004), Czinkota and Ronkainen (2006) and Hollensen (2004). Among them are employment opportunities; source of foreign exchange; development of new technologies; creation of forward and backward linkages; improvement of organizations' financial position; ability to develop competitive advantages; enrich management skills and facilitate the growth of the organization.

A number of studies have identified that management play a critical role in the decision to export. According to Cavusgil et al. (1993), managerial factors can facilitate or inhibit the decision to engage in export operations, while Leonidou (2003) states that export managers are directors of export operations. Furthermore, according to Seifert and Ford, (1989) and White et al. (1998), managers have more knowledge on the export goals of the organization.

Therefore, the aim of the study is to identify the relationship between export performance and export development. In addition, the influences of managements' motivations on export performance and on the future expansion plans or export development are also tested. Finally, the mediation effect of managements' motivation on the relationship between export performance and export development is tested.

The following part discusses the previous studies relating to export performance, export development and motivation.

\section{Export Performance and Export Development}

Different terms have been used in explaining export performance. Among them are international performance (Cavusgil and Zou, 1994), export performance (Ural, 2009), international marketplace performance (O'Cass and Weerawardena, 2009), economic international performance (Blesa and Ripolle's, 2008), export performance improvement (Lages and Montgomery, 2005) and export success (Bijmolt and Zwart, 1994), among others.

Export performance has been broadly measured using financial or objective measures (sales, profit), non-financial or subjective measures (satisfaction, goal achievement) and also composite measures. Export sales have been used by a majority of researchers to measure export performance. They include Ural (2009), Ko"ksal (2008), Racela et al. (2007), Shamsuddoha and Ali (2006), Lages and Montgomery (2005). Export sales growth have also been used as form of export performance measure (O'Sullivan and Butler, 2009; Shamsuddoha and Ali, 2006; Francis and Collins-Dodd, 2004).

Other forms of measures are export profit (Blesa and Ripolle's, 2008; Shamsuddoha and Ali, 2006) and profitability (Ural, 2009; O'Sullivan and Butler, 2009; Salavou and Halikias, 2009; Blesa and Ripolle's, 2008; Ko"ksal, 2008; Racela et al., 2007; Lages and Montgomery, 2005). Satisfaction have been measured in terms of customer (O'Cass and Weerawardena, 2009), market performance (O'Sullivan and Butler, 2009), level of export performance (Lee and Griffith, 2004) and export operation (Akyol and Akehurst, 2003). Racela et al. (2007) measure satisfaction on a variety of criteria such as 
export sales, export profitability, export market share and rate of new market entry. Market share achievement has also been used to measure export performance level by Ural (2009), O'Cass and Weerawardena (2009), Blesa and Ripolle's (2008) and Ko"ksal (2008). Measuring export performance through export intensity is applied by Francis and Collins-Dodd (2004), Alonso and Donoso (2000) and SuarezOrtega and Alamo-Vera, (2005). Lages and Montgomery (2004) and Akyol and Akehurst (2003) used overall market performance as a form of measure.

Thus, it can be seen that there are many measures of export performance used over the years. The research adopts the measurement Zou et al. (1998), since it covers a broad area. Export performance is measured using financial export performance, strategic export performance and satisfaction with the export venture.

The measurement of export development or export expansion has not been researched widely in internationalization related studies. Among the existing studies is Francis and Collins-Dodd (2004) who referred export development as export expansion. Among the measurements used are in terms of new markets and/or new products, new geographic or new product markets (next year and the next three years) and increase export intensity "next year" and "next three years". Entering new markets is also used by O'Cass and Weerawardena (2009) and Shamsuddoha and Ali (2006); however, it is used to measure export performance, while rate of new market entry is applied by Racela et al. (2007) for measuring performance satisfaction. White et al. (1998) on the other hand use development of firms' market to measure the effect of internationalization in the future. Lim et al. (2006) use measures such as 'expand their export sales through additional product introduction' and 'expand their export sales through international market expansion' among others to measure export market involvement. This research adopts the measurement used by Francis and
Collins-Dodd (2004) and White et al. (1998) as a foundation in measuring export development. The measurements used are increase export sales, enter new market, enter into other modes of international venture and introduce new product.

Due to the high linkage between the measures of export development with export performance, it is proposed that export performance might influence export development direction in the future. Thus, the following hypothesis is formulated.

H1: There is a relationship between financial export performance and export development.

H2: There is a relationship between strategic export performance and export development.

H3: There is a relationship between satisfaction with the export venture and export development.

\section{Managements' Motivation}

Motivation is commonly referred to as stimuli in a number of researches (Leonidou et al. 2007; Rundh, 2007; Katsikeas, 1996). Leonidou et al. (2007) define motivation as factors that triggers firm to consider starting and developing export, and stimuli play an active role at any export development stage (Leonidou and Katsikeas, 1996; Morgan, 1997).

According to Rabino (1980), export market opportunities that are perceived to be advantageous, serve as a stimulus for exporting. Supporting studies are by Terpstra and Yu (1988) and Russow and Okoroafo (1996), who identified that market potential (size and growth) is an important determinant of market entry. Other studies are by Bradley (2004), who states that unlimited opportunities which exist in the overseas market can be exploited through exporting. Successful exporters point out that firm's willingness to search for foreign markets is a primary determinant of profit (Blesa and Ripolle's, 2008). The expectation 
on the perceived attractiveness of export markets has been ranked top positions in most studies of having the greatest stimulating effect on exporting (Rabino, 1980; Johnston and Czinkota, 1982; Jaffe et al., 1988; Ifju and Bush, 1993; Katsikeas and Piercy, 1993; Leonidou, 1998a; Tzokas et al., 2000; Westhead et al., 2002). In addition, Leonidou et al. (2007) who did a review of stimulating factors rank identification of better opportunities to have a high impact.

Management's expectation of sales, profit and growth is seen also as a primary motivator (Rundh, 2007; Bilkey, 1982; Katsikeas, 1994 and Cavusgil and Nevin; 1981). These factors have been also linked for intentions for future growth (Rundh, 2007; Leonidou et al., 2007). Leonidou et al. (2007) found that potential for sales or profit and growth have a very high impact on ranking stimuli.

Management will also be motivated to export if they regard that they have advantages of a marketable or unique product. This has been mentioned by Cavusgil and Nevin (1981), Cavusgil and Zou (1994), Bilkey (1982) and Katsikeas (1994). This factor is found to stimulate international activities (Rundh, 2007). Furthermore, products that have superior qualities and are unique are indicated to be among the major reasons for exporting (Johnston and Czinkota, 1982; Tesar and Tarleton, 1982; Kaynak and Kothari, 1984; Jaffe et al., 1988, Koh, 1989). Unique product advantages are found to be critical for success in international market (Diamantopoulos and Inglis, 1988; Li et al., 1999) and attract the attention of foreign customers (Leonidou et al., 2007). Nevertheless, contradictory finding is reported by Katsikeas et al (1996) who deduced that having a unique product did not mean that it has a significant relationship with export performance.

Leonidou et al. (2007) found enthusiasm and drive is a force towards the initiation and development of successful export business and ranked it to have a high impact. Leonidou et al. (1998) found managers who are internationally-minded and have a special favorable interest in export activities. Contradictory finding is reported by Katsikeas et al. (1996), who found no significant relationship between management belief of importance of exporting and export performance.

According to Wheeler et al. (2008), motivation has a strong positive effect on export performance. Therefore, the following hypotheses are formulated on the influence of managements' motivation and export performance.

H4: There is a relationship between managements' motivation and financial export performance.

H5: There is a relationship between managements' motivation and strategic export performance.

H6: There is a relationship between managements' motivation and satisfaction with the export venture.

Expansion of export or export development is usually based on the top management's decision or motivation since they decide the future direction of their organization. According to Lado et al. (2004) motivation towards proactive exporting is necessary for firms to expand their sales base. Similarly, the need for profit is one of the reason that influence managers decision on where and how to grow (Shapira, 1995). Thus, managements' motivation influence on export development is tested. In addition, motivation is also tested on its indirect influence between export performance and future export development. The following hypotheses are formulated to test them.

H7: There is a relationship between managements' motivation and export development.

H8: Managements' motivation will mediate the relationship between export performance and export development. 


\section{Methodology}

The data is collected from exporting organizations based on the Export Directory provided by the Malaysian Trade and Development Corporation (MATRADE). The selection of industries is based on the previously drawn selection of clusters in the Industrial Master Plan 3; a major plan drawn up by the Malaysian government in spearheading the development of the industries. Seven industries (palm oil products, food-based industries, machinery and equipment, electrical and electronics products, textile and apparel, pharmaceutical and medical products) are randomly selected and based on these industries, a total of around 1,439 questionnaires have been sent to the resource person of the industries who serves in a managerial position and is knowledgeable in exporting activities. The choice of organizations is based on the completeness of the information in the database. A self-addressed stamped envelope is attached in order to ease the process of the return of the questionnaires. Around 215 questionnaires were returned and 212 were considered in the study. 3 questionnaires are found not usable since they were returned unanswered. The response rate of $14.9 \%$ is considered acceptable since it is common in mail survey and industry-related respondents (Erdogan and Tagg, 2003).

\section{Results}

The profiles of the respondents are discussed first. The majority (37\%) of the respondents' are those in the age group of 41 to 50 years. The education level of respondents is considered high since more than half of the respondents have a degree. This is not surprising since the respondents are mainly in a managerial position. In addition, more than $75 \%$ of the respondents have some level of overseas exposure. Those with working experience accounted for $75 \%$ of the respondents. The organizations range from those operating for 3 years to more than 15 years. However, those operating more than 9 years are around $70 \%$. In terms of size which is measured in terms of employees, most of the firms have 100-150 employees.

Correlation analysis is then conducted to identify the relationship between export performance and export development (ED) and test the first three hypotheses. The result is presented in Table 1. All the export performance measures, financial export performance (FP), strategic export performance (SP) and satisfaction with the export venture (SA) are found to be positively correlated with export development (ED). Therefore, H1, H2 and H3 are accepted. This means that export performance influences the decision to further develop the exporting activity. This is because when the organizations perform well in export, the prospects of progressing or developing export is seen to be positive and thus, influence the intention to develop.

Table 1: Correlation Analysis Results (Export Performance and Export Development)

\begin{tabular}{|l|l|}
\hline & $\begin{array}{l}\text { Export Development } \\
\text { (ED) }\end{array}$ \\
\hline Financial export performance (FP) & $0.282^{* *}$ \\
\hline Strategic export performance (SP) & $0.278^{* *}$ \\
\hline Satisfaction with the export venture (SA) & $0.432^{* *}$ \\
\hline
\end{tabular}

Next, managements' motivation (MM) is correlated with export performance and export development. The results in Table 2 indicate positive relationships in all the hypotheses tested. This shows that export performance is influenced by managements' motivation. Managements' motivation is also correlated with export development. The 
findings indicate that managements' motivation plays a positive role in the decision to develop export. Thus, H4, H5, H6 and $\mathrm{H} 7$ are accepted.

Table 2: Correlation Analysis Results (Managements' Motivation and Export Development)

\begin{tabular}{|l|l|}
\hline & $\begin{array}{l}\text { Managements' } \\
\text { Motivation (MM) }\end{array}$ \\
\hline Financial export performance (FP) & $0.207^{* *}$ \\
\hline Strategic export performance (SP) & $0.271^{* *}$ \\
\hline Satisfaction with the export venture (SA) & $0.252^{* *}$ \\
\hline Export Development (ED) & $0.272^{* *}$ \\
\hline
\end{tabular}

Next, the research seeks to identify whether managements' motivation mediates the relationship between management competencies and export development. In testing the mediation effects, three conditions have to be satisfied (Barron and Kenny, 1986). First, export performance, the independent variable, is regressed with export development, and export performance must be associated with export development. Next, managements' motivation, the mediating variable, is regressed with export performance where managements' motivation is the outcome variable. If there is a regression, this satisfies the conditions to test mediation effects. Finally, export performance and managements' motivation is regressed with export development. The result is presented in Table 3 . The result obtained identifies that managements' motivation partially mediates the relationship between export performance and export development. Further analysis indicates that this mediation is significant. The hypothesis is thus supported. Therefore, this means that managements' motivation and export performance are necessary when considering export development or that they influence the decision in terms of expansion in export in the future.

Table 3: Mediation effect results (Export Performance and Export Development)

\begin{tabular}{|c|c|c|c|c|}
\hline & $\beta$ & Std Error & & Interpretation \\
\hline $\mathrm{FP} \longrightarrow \mathrm{ED}$ & 0.192 & 0.049 & 0.000 & \\
\hline $\mathrm{FP} \longrightarrow \mathrm{MM}$ & 0.127 & 0.041 & 0.002 & \\
\hline $\mathrm{FP}$ and $\mathrm{MM} \longrightarrow \mathrm{ED}$ & & & & $\begin{array}{l}\text { Partial mediation } \\
\text {-signficant }\end{array}$ \\
\hline $\mathrm{FP}$ & 0.158 & 0.049 & 0.001 & \\
\hline $\mathrm{OF}$ & 0.272 & 0.079 & 0.001 & \\
\hline $\mathrm{SP} \longrightarrow \mathrm{ED}$ & 0.221 & 0.053 & 0.000 & \\
\hline $\mathrm{SP} \longrightarrow \mathrm{MM}$ & 0.181 & 0.044 & 0.000 & \\
\hline $\mathrm{SP}$ and $\mathrm{MM} \longrightarrow \mathrm{ED}$ & & & & $\begin{array}{l}\text { Partial mediation } \\
\text {-signficant }\end{array}$ \\
\hline SP & 0.175 & 0.054 & 0.001 & \\
\hline MM & 0.254 & 0.081 & 0.002 & \\
\hline $\mathrm{SA} \longrightarrow \mathrm{ED}$ & 0.351 & 0.051 & 0.000 & \\
\hline $\mathrm{SA} \longrightarrow \mathrm{MM}$ & 0.171 & 0.045 & 0.000 & \\
\hline $\mathrm{SA}$ and $\mathrm{MM} \longrightarrow \mathrm{ED}$ & & & & $\begin{array}{l}\text { Partial mediation } \\
\text {-signficant }\end{array}$ \\
\hline SA & 0.315 & 0.051 & 0.000 & \\
\hline ED & 0.208 & 0.076 & 0.006 & \\
\hline
\end{tabular}




\section{Discussion}

Export performance is found to significantly influence export development. All the three forms of measurement (financial export performance, strategic export performance and satisfaction with the export venture) show similar results. The result implies that export performance of an organization influences the decision on future expansion plans. This is because when exporting show positive results; further development of export activity is considered. Another significant finding is that managements' motivation is found to be significantly related to export performance and also export development. Therefore, this indicates when there is motivation, it influences export performance. This finding is in line with previous studies whereby motivation, such as export market attractiveness were ranked top positions by a number of researchers such as Tzokas et al. (2000), Westhead et al. (2002) and Leonidou et al. (2007). Furthermore, the results in terms of potential financial benefits, such as sales and profit and potential for growth are supported by previous studies, such as Rundh (2007), Bilkey (1982), Katsikeas (1994) and Cavusgil and Nevin (1981). In addition, unique product advantages as a motivator is supported by Diamantopoulos and Inglis (1988) and Li et al. (1999) who found it critical for success in the international market. Similarly, management interest or urge as motivator is supported by Leonidou et al., (2007).

The mediating effect of the managements' motivation on the relationship between export performance and export development shows that managements' motivation is critical in the decision to develop export. Even though performance of the export activity is impressive, the direction of the future of export still depends on the management. The result supports this, whereby managements' motivation has an impact on the shape of decisions for future export expansion. The motivation is caused by financial benefits, opportunities available, the product advantage and the overall interest of the management.

\section{Conclusion}

The study has found there is a direct link between export performance and export development. This means that organizations that perform well in export are more likely to develop the export at a higher level. Therefore, policy makers should take steps in providing assistance that could ensure a satisfactory export performance of organizations. In addition, the managements' motivation is found to influence both export performance and export development. Therefore, the benefit of exporting should be highlighted to motivate the promotion of export. Organizations that have been performing successfully should be guided, and incentives to encourage export should be provided. Opportunities should also be provided through promotions activities. Organizations should be encouraged to participate in programs that promote export development. Closer linkage between organizations should be built within similar industries and the government may serve to facilitate the creation of such linkages. The study has its limitation. Firstly, the sample size is small which affects in turn the level of generalizability. However, this can be remedied in future study with a larger sample size. Lastly, the current study involves several industries, hence future study could consider performing a comparative study to identify the differences among industries.

\section{References}

Aaby, N.- E. \& Slater, S. F. (1989). "Management Influence on Export Performance: A Review of the Empirical Literature," International Marketing Review, 6 (4), 7-26.

Akyol, A. \& Akehurst, G. (2003). "An Investigation of Export Performance Variations Related to Corporate Export 
Market Orientation," European Business Review, 15 (1), 5-19.

Albaum, G., Strandscov, J. \& Duerr, E. (2004). 'International Marketing and Export Management,' Addison-Wesley, Wokingham.

Alonso, J. A. \& Donoso, V. (2000). "Modelizacion del Comportamiento de la Empresa Exportadora Espan Ola," Informacio'n Comercial Españ ola, 788, 3558.

Bijmolt, T. H. A. \& Zwart, P. S. (1994). “The Impact of Internal Factors on the Export Success of Dutch Small and Medium sized firms," Journal of Small Business Management, April, 69-82.

Bilkey, W. J. (1982). "Variables Associated with Export Profitability," Journal of International Business, 13, 39-95.

Blesa, A. \& Ripolle's, M. (2008). “The Influence of Marketing Capabilities on Economic International Performance," International Marketing Review, 25 (6), 651673.

Bradley, F. (2004). 'International Marketing Strategy,' Prentice-Hall, Englewood Cliffs, NJ.

Cadogan, J. W., Sundqvist, S., Salminen, R. T. \& Puumalainen, K. (2002). "Market-Oriented Behavior: Comparing Service with Product Exporters," European Journal of Marketing, 36 (9), 1076-102.

Cavusgil, S. T. \& Nevin, J. R. (1981). “Internal Determinants of Export Marketing Behaviour: An Empirical Investigation," Journal of Marketing Research, 18 (4), 114-9.

Cavusgil, S. T. \& Zou, S. (1994). "Marketing Strategy-Performance Relationship: An Investigation of the Empirical Link in Export Market Ventures," Journal of Marketing, 58 (1), 1-21.

Cavusgil, S. T., Zou, S. \& Naidu, G. M. (1993). "Product and Promotion Adaptation in
Export Ventures: An Empirical Investigation," Journal of International Business Studies, 24 (3), 479-506.

Czinkota, M. R. \& Ronkainen, I. A. (2006). 'International Marketing,' The Dryden Press, Hinsdale, IL.

Dhanaraj, C. \& Beamish, P. W. (2003). "A Resource Based Approach to the Study of Export Performance," Journal of Small Business Management, 41 (3), 242-261.

Diamantopoulos, A. \& Inglis, K. (1988). "Identifying Differences between High- and Low-Involvement Exporters," International Marketing Review, 5 (2), 52-60.

Erdogan , B. Z. \& Tagg, S. (2003). "The Advertising Agency Manager's Response Patterns to a Mail Survey and Follow- Ups," Marketing Intelligence and Planning, 21 (6), 392-399.

Francis, J. \& Collins-Dodd, C. (2004). “Impact of Export Promotion Programs on Firm Competencies, Strategies and Performance, The case of Canadian high-technology SMEs," International Marketing Review, 21 (4/5), 474-495.

Hollensen, S. (2004). 'Global Marketing: A Decision-Oriented Approach,' Pearson Education Limited, Harlow.

Ibeh, K. I. N. \& Young, S. (2001). “Exporting as an Entrepreneurial Act, An Empirical tudy of Nigerian Firms, " European Journal of Marketing, 35 (5/6), 566-586.

Ifju, P. A. \& Bush, R. J. (1993). "Export Barriers and Incentives in the Eastern Hardwood Lumber Industry," Forest Products Journal, 43 (3), 45-8.

Jaffe, E. D., Nebenzahl, I. D. \& Pasternak, D. H. (1989). "The Export Behaviour of Small Israeli Manufacturers," Journal of Global Marketing, 2 (2), 27-49. 
Johnston, W. J. \& Czinkota, M. R. (1982). 'Managerial Motivations as Determinants of Industrial Export Behaviour,' in Czinkota, M.R. and Tesar, G. (eds), Export Management: An International Context, Praeger Publishers, New York, NY.

Katsikeas, C. S. (1994). "Export Competitive Advantages: The Relevance of Firm Characteristics," International Marketing Review, 11 (3), 33-53.

Katsikeas, C. S. \& Piercy, N. F. (1993). “LongTerm Export Stimuli and Firm Characteristics in a European LDC," Journal of International Marketing, 1 (3), 23-47.

Katsikeas, C. S., Piercy, N. F. \& Ioannidis, C. (1996). "Determinants of Export Performance in a European Context," European Journal of Marketing, 30 (6), 6-35.

Kaynak, E. \& Kothari, V. (1984). "Export Behaviour of Small- and Medium-Sized Manufacturers: Some Policy Guidelines For International Marketers," Management International Review, 24 (2), 61-9.

Koh, A. C. (1989). 'An Evaluation of the Current Marketing Practices of United States Firms,' Developments in Marketing Science, 12, 198-203.

Köksal, M. H. (2008). "How Export Marketing Research Affects Company Performance," Marketing Intelligence and Planning, 26 (4), 416-430.

Lado, N., Martínez-Ros, E. \& Valenzuela, A. (2004). "Identifying Successful Marketing Strategies by Export Regional Destination," International Marketing Review 21(6), 573597.

Lages, L. F. \& Montgomery, D. B. (2004). "Export Performance as an Antecedent of Export Commitment and Marketing Strategy Adaptation. Evidence from Small and Medium-sized Exporters," European Journal of Marketing, 38 (9/10), 1186-1214.
Lages, L. F. \& Montgomery, D. B. (2005). “The Relationship between Export Assistance and Performance Improvement in Portuguese Export Ventures: An Empirical Test of the Mediating Role of Pricing Strategy Adaptation," European Journal of Marketing, 39 (7/8), 755-784.

Lee, C. \& Griffith, D. A. (2004). "The Marketing Strategy-Performance Relationship in an Export-Driven Developing Economy. A Korean illustration," International Marketing Review, 21 (3), 321334.

Leonidas C. L. (2003). "Overcoming the Limits of Exporting Research Using the Relational Paradigm," International Marketing Review, 20 (2), 129-141.

Leonidou, L. C. (1998a). "Factors Stimulating Export Business: An Empirical Investigation," Journal of Applied Business Research, 14 (2), 43-68.

Leonidou, L. C. \& Katsikeas, C. S. (1996). "The Export Development Process: An Integrative Review of Empirical Models," Journal of International Business Studies, 27 (3), 51751.

Leonidou, L. C., Katsikeas, C. S., Palihawadana, D. \& Spyropoulou, S. (2007). "An Analytical Review of the Factors Stimulating Smaller Firms to Export : Implications for PolicyMakers," International Marketing Review, 24 (6), 735-770.

Leonidou, L. C., Katsikeas, C. S. \& Piercy, N. F. (1998). "Identifying Managerial Influences on Exporting: Past Research and Future Directions," Journal of International Marketing, 6 (2), 74-102.

Lim, J. S., Sharkey, T. W. \& Heinrichs, J. H. (2006). "Strategic Impact of New Product Development on Export Involvement," European Journal of Marketing, 40 (1/2), 4460. 
Li, T., Nicholls, J. A. F. \& Roslow, S. (1999). "The Relationships between Market-Driven Learning and New Product Success in Export Markets," International Marketing Review, 16 (6), 476-503.

Morgan, R. E. (1997). "Export Stimuli and Export Barriers: Evidence from Empirical Research Studies," European Business Review, 97 (2), 68-79.

O’Cass, A. \& Julian, C. (2003). “Examining Firm and Environmental Influences on Export Marketing Mix Strategy and Export Performance of Australian Exporters," European Journal of Marketing, 37 (3/4), 366-384.

O'Cass, A. \& Weerawardena, J. (2009). "Examining the role of International Entrepreneurship, Innovation and International Market Performance in SME Internationalization," European Journal of Marketing, 43 (11/12), 1325-1348.

O'Sullivan, D. \& Butler, P. (2009). "Market Orientation and Enterprise Policy," European Journal of Marketing, 43 (11/12), 1349-1364.

Rabino, S. (1980). "An Examination of Barriers to Exporting Encountered by Small Manufacturing Companies," Management International Review, 20, 67-73.

Racela, 0. C., Chaikittisilpa, C. \& Thoumrungroje, A. (2007). "Market Orientation, International Business Relationships and Perceived Export Performance," International Marketing Review, 24 (2), 144-163.

Rundh, B. (2007). "International Marketing Behaviour amongst Exporting Firms," European Journal of Marketing, 41 (1/2), 181-198.

Russow, L. C. \& Okoroafo, S. C. (1996). “On the Way towards Developing a Global Screening Model," International Marketing Review, 13 (1), 46-64.
Salavou, H. E. \& Halikias, J. (2009). "Strategy Types of Exporting Firms :A View on the basis of Competitive Advantage," European Business Review, 21(2), 144-158.

Seifert, B. \& Ford, J. (1989). “Are Exporting Firms Modifying Their Product Pricing and Promotion Strategies?,", International Marketing Review, 6 (6), 53-68.

Shamsuddoha, A. K. \& Ali, M. Y. (2006). "Mediated Effects of Export Promotion Programs on Firms Export Performance," Asia Pacific Journal of Marketing and Logistics, 18 (2), 93-110.

Shapira, Z. (1995). 'Risk Taking,' Russell Sage Foundation, New York, NY.

Styles, C. \& Ambler, T. (1994). "Successful Export Practice: The UK Experience," International Marketing Review, 11, 6, 23-47.

Suárez-Ortega, S. M. \& Álamo-Vera, F. R. (2005). "Smes' Internationalization: Firms and Managerial Factors," International Journal of Entrepreneurial Behaviour \& Research, 11 (4), 258-279.

Terpstra, V. \& Yu, C.- M. (1988). "Determinants of Foreign Investment of US Advertising Agencies," Journal of International Business Studies, 19 (1), 33-46.

Tesar, G. \& Tarleton, J. S. (1982). 'Comparison of Wisconsin and Virginia Small and Medium Sized Exporters: Aggressive and Passive Exporters,' in Czinkota, M.R. and Tesar, G. (eds), Export Management: An International Context, Praeger Publishers, New York, NY, 85-112.

Tzokas, N., Hart, S., Argouslidis, P. \& Saren, M. (2000). "Strategic Pricing in Export Markets: Empirical Evidence from the UK," International Business Review, 9 (10), 95-117.

Ural, T. (2009). "The Effects of Relationship Quality on Export Performance A Classification of Small and Medium-Sized Turkish Exporting Firms Operating in Single 
11 Journal of Organizational Management Studies

Export-Market Ventures," European Journal of Marketing, 43 (1/2), 139-168.

Westhead, P., Wright, M. \& Ucbasaran, D. (2002). "International Market Selection Strategies Selected by 'Micro' and 'Small Firms," Omega - The International Journal of Management Science, 30, 51-68.

Wheeler, C., Ibeh, K. \& Dimitratos, P. (2008). "UK Export Performance Research: Review and Implications," International Small Business Journal, 26 (2), 207-239.

White, D. S., Griffith, D. A. \& Ryans, Jr, J. K. (1998). "Measuring Export Performance in Service Industries," International Marketing Review, 15 (3) 188-204.

Zou, S., Taylor, C. R. \& Osland, G. E. (1998). 'The EXPERF Scale: A Cross-National Export Performance Measure,' Journal of International Marketing, 6 (3), 37-58. 